\title{
Model Context, Input, Process, and Product (CIPP) pada Career Development Center (CDC) untuk Evaluasi Program Layanan Informasi Karir SMK
}

\author{
Siti Hajar Thaitami1*, Giatman ${ }^{2}$, Ambiyar ${ }^{3}$, Nizwardi Jalinus ${ }^{4}$, Syahril5, \\ Wakhinuddin 6 \\ 1,2,3,4,5,6 Fakultas Teknik, Universitas Negeri Padang, Padang, Indonesia
}

\section{ART ICLE INFO}

Article history

Received May 13, 2021

Revised May 20, 2021

Accepted June 29, 2021

Available online August 25, 2021

Kata Kunci:

Evaluasi, CIPP, Layanan

Informasi Karir, CDC

\section{Keywords:}

Evaluation, CIPP, Career

Information Services, $C D C$

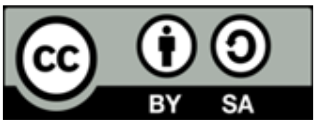

This is an open access article under the CC BY-SA license.

Copyright (@) 2021 by Author. Published by Universitas Pendidikan Ganesha.

\begin{abstract}
A B S T R A K
Permasalahan yang terjadi saat ini yaitu masih banyak kasus pengangguran. Hal ini disebabkan karena alumni yang tidak mengetahui lowongan pekerjaan yang sesuai dengan kemampuan yang dimilikinya. Tujuan penelitian ini yaitu menganalisis penerapan model evaluasi CIPP (context, input, process, and product) terhadap hasil layanan informasi karir. Penelitian ini merupakan penelitian kualitatif dengan menggunakan model evaluasi CIPP untuk mengevaluasi tiap komponen konteks, input, proses, dan produk dalam mencapai proses layanan informasi karir yang efektif. Pengumpulan data utama menggunakan wawancara, sedangkan untuk data pendukung menggunakan angket, observasi, dan dokumentasi. Data hasil pengumpulan data dianalisis secara triangulasi. Teknik yang digunakan untuk menganalisis data yaitu analisis deskriptif kualitatif. Hasil penelitian yaitu Context (evaluasi konteks) pelaksanaan kegiatan layanan informasi karir dikatakan sangat baik, namun kekurangannya yaitu pada indicator. Input (evaluasi masukan) sudah sangat baik. Process (evaluasi proses) pada tahap dikatakan baik namun untuk perbaikan pada tahap setelah melaksanakan layanan. Product (evaluasi hasil) secara keseluruhan program pelaksanaan layanan informasi karir yang dilakukan sudah dikatakan baik.
\end{abstract}

\section{A B S T R A C T}

The problem that occurs today is that there are still many cases of unemployment. This is because alumni do not know about job vacancies that match their abilities. This study aims to analyze the application of the CIPP evaluation model (Context, input, process, and product) to the results of career information services. This qualitative research uses the CIPP evaluation model to evaluate each component of Context, input, process, and product in achieving an effective career information service process. The primary data collection uses interviews, while for supporting data using questionnaires, observations, and documentation. The data from the data collection were analyzed by triangulation. The technique used to analyze the data is descriptive qualitative analysis. The study results are Context (context evaluation); the implementation of career information service activities is very good, but the drawback is the indicators. Input (input evaluation) has been very good. Process (process evaluation) is said to be good but for improvement at the stage after carrying out the service. The product (evaluation of results) as a whole is said to be good.

\section{PENDAHULUAN}

A career is a person's position or occupation during his working life in an organization (Briscoe et al., 2021; Ives et al., 2020). From an employee's point of view, answers are essential. Everyone wants an appropriate position and abilities (Aggari et al., 2020; Buenconsejo \& Datu, 2020). A high position will affect a higher salary. In addition, the duties and responsibilities will also be more significant so that better knowledge is needed to hold high positions in a particular company (C. C. Chan, 2020; Hirschi et al., 2021). It is what causes when someone enters the world of work, that person will ask whether the goal as the highest expected position will be achieved in the workplace. Career development is one way to improve careers (Storm et al., 2021; Wilkins et al., 2021). 
Career is the overall position/job/position that a person can occupy during his working life in an organization or several organizations (McAleavy et al., 2021; Smithson et al., 2021). Development is a personal improvement made by a person in achieving a career plan. Career development can be interpreted as a process of increasing individual work abilities achieved in order to achieve the desired career (Emamaullee et al., 2021; Steeb et al., 2021). Individuals need to develop their careers. The development of career centres affects individual career development (Yamao et al., 2020; Yano et al., 2021). Someone who gets career development while in college will make it easier to adapt to the community. No matter how reasonable and realistic career goals accompany the plans or careers made by a worker, the plan will not come true without systematic and programmatic career development (LoyarteLópez et al., 2020; Rakhab et al., 2021). This is why career planning is a decision that must be made now regarding what to do in the future. Human resources are also essential in these development activities.

However, the current problem is that there are still many cases of unemployment (Harianti et al., 2020; Indayani \& Hartono, 2020; Sugianto \& Yul, 2020). This problem also occurs in one of the alumni of a vocational high school. Based on the results of a preliminary study in the form of interviews and documentation of several administrators from the CDC at SMK N 8, it was found that the problem was the problem of the number of unemployed college alumni and the lack of knowledge of job vacancies. Many alumni do not know about job vacancies that match their abilities. Based on the results of interviews, it was also found that alumni were too picky about jobs, so the job vacancies they wanted were challenging to find.

Based on these problems, it is necessary to conduct a research evaluation of the implementation of career information services. Based on interviews conducted with the CDC management of SMK N 8 during the preliminary study, it was stated that the Career Development Center of SMK N 8 (P2K/CDC $\mathrm{SMK}$ ) is an interactive vehicle to support efforts to increase networking by establishing an information network on job and business opportunities. Business development, solving business problems, developing the quality of human resources, and aligning human resource needs with the business world in South Kalimantan. CDC SMK N 8 has various services for students and alumni, such as career counselling, hard skills training, soft skills training, scholarship information, career information, and tracer studies. These services serve to develop students' careers and enter the world of work in the future. One of the missions of CDCSMK N 8 is to improve the quality of students and alumni to align with the needs of the job market. The function and purpose of the CDC of SMK N 8 are to provide information about careers and train students and alumni in the fields of soft skills and hard skills as well as to accommodate and facilitate alumni in finding jobs, and to accommodate companies in recruiting employees, mainly from alumni of SMK N 8, hence the presence of CDC SMK N 8 is very precise.

One of the services from CDC SMK N 8 is a career information service. The programs in the career information service from CDC SMK N 8 are job vacancy information, campus hiring, and career seminars. Job vacancy information contains the availability of job opportunities from job seekers (companies) to job seekers. The purpose of Campus Hiring is to accelerate the job recruitment process for students, especially alumni, in building careers and entering the professional world (Baruffaldi et al., 2016; Shubeck et al., 2020). Campus Hiring is a company's process of recruiting students and fresh graduates from universities. Such companies will provide students with the best talents to work in their companies (Aghaei et al., 2021; Duprez et al., 2021). Companies use this strategy to attract students who need experience for internships or recent graduates interested in working full-time. When conducting campus hiring, companies can focus on specific institutions that match the company's needs (Vasli et al., 2021; Veselova et al., 2021). Previous research findings also state that students or alumni with good abilities will find it easier to find work (Baert et al., 2021; Hou et al., 2020). Other research findings also state that students who know about job opportunities will find it easy to get a job (Abulhassn \& Roberts, 2021; C. S. C. Chan, 2021). It can be concluded that students' knowledge of job opportunities is essential. This study aims to analyze the career information service program implemented by CDC at SMK N 8. It is hoped that the career information service program that has been owned can help alumni looking for work.

\section{METODE}

This qualitative research uses the CIPP evaluation model to evaluate each component of Context, Input, Process, and Product in achieving an effective career information service process. This research was conducted at the CDC at SMK N 8. The service program under study located at the institution, namely the career information service program. This study intends to analyze how the evaluation results of the implementation of career information service programs with the CIPP model at the Career Development Center (CDC) SMK N 8. This study uses a qualitative approach with data collection techniques: interviews, questionnaires, observation, and documentation. Interviews and questionnaires were used to find out the 
problems that occurred in the field. Documentation is done to record all activities carried out during the research. The data from the data collection were analyzed by triangulation. The technique used to analyze the data is descriptive qualitative analysis.

\section{HASIL DAN PEMBAHASAN}

\section{Hasil}

The first evaluation carried out is on the Context component. Evaluation of the context component is the identification of the program background. The results of the research on the implementation of the career information service program at CDC SMK N 8 Banjarmasin on the Context component of the implementation of career information services based on the results of interviews, questionnaires and documentation, the implementation of this service is included in the implemented category because the score obtained exceeds the average value that has been formulated, as well as the explanation from the results of interviews and existing documentation.

In the context indicator, all stakeholders involved in CDC (chairman, management, vicechancellor, vice dean) coordinate together to determine the goals of CDC career information services, conduct socialization with stakeholders, career information services made by the goals of career information services. namely to understand self-potential, career interests, types of work, and career planning, services made relevant to relevant laws and the existence of a decree (SK), are preventive (prevents wrong actions in making decisions) Examples of activities: Career socialization is distributive (broadening insight in work and position), referential (studying, asking questions, and digging deeper about careers) Examples of activities: Campus hiring, job vacancies information, job fairs) Examples of activities: Career training, CDC distributes questionnaires or interviews to students regarding career needs, and a written report on the results of the need assessment ent from the CDC secretary all went well. All indicators can be said to have been implemented, so it is necessary to maintain it to perfect the career information service program in the career information service program. Even though from the documentation there are no results and reports on the needs assessment of the career needs of students and alumni. For the CDC indicator, distributing questionnaires or interviews to students regarding career needs to be discussed with the stakeholders involved to know well the career needs of students and alumni.

The third evaluation carried out is on the process component. The research results on the process component can be concluded that the implementation of career information services is said to have gone healthy-provision of adequate facilities and infrastructure. In addition, careful preparation of the material in the activities and the speakers presented. However, the indicators for organizing service activities and activating service participants are not carried out directly by the CDC management. However, by resource persons and moderators who are brought in for career information service activities. However, this is going quite well considering that CDC is here as an interactive vehicle to support efforts to increase networking by establishing an information network on job and business opportunities, developing the quality of human resources, and aligning human resource needs with the business world, especially in South Kalimantan. The provision of follow-up is expected to be discussed so that participants can get complete career information services. The fourth evaluation carried out is on the product component. The results of research on product components, namely students and alumni, benefit from implementing career information service activities. Career information services provided can provide more knowledge about careers, future career planning, new things and changes in themselves in a more positive direction. In addition, there is information on job vacancies and recruitment from companies that are very helpful for alumni in finding and getting jobs. It shows that career information service activities positively influence students and alumni to develop themselves in a better direction.

\section{Pembahasan}

Career information service activities can provide good service for alumni. Implementing career information service activities can provide more knowledge about careers for alumni (Crowne et al., 2020; Ho et al., 2020). In addition, this service is also able to provide future career planning. Difficulties in making decisions can be avoided with this service (Yada et al., 2021; Yano et al., 2021). Students need adequate information regarding matters relating to the world of careers. It causes students to need assistance and guidance to understand their conditions and characteristics regarding their talents, interests, strengths and weaknesses, and the goals they want to achieve (Ives et al., 2020; Lee et al., 2020). Through this service, there is a change in alumni towards a more positive direction. The existence of job vacancies or company recruitment information is beneficial for alumni in finding and getting jobs. It will reduce unemployment for new graduates. Through information services, students can receive and 
understand various information used as consideration in decision making (Kautish et al., 2021; LaForce et al., 2017).

This shows that career information service activities will positively influence students or alumni in developing themselves in a better direction (Alfaiz et al., 2021; Creed et al., 2012). Information services are one type of service that is included in the counselling field, which is very important to help students avoid various problems that can interfere with the achievement of student development, which is related to personal, social, or career (Buenconsejo \& Datu, 2020; Ives et al., 2020). The purpose of the career information service has been achieved, namely to understand students and alumni about themselves, especially in the career field. In addition, this service will also assist students in making informed career decisions based on the information they obtain (C. C. Chan, 2020; Crowne et al., 2020).

The findings of previous studies also stated that information services are essential for students (Kautish et al., 2021; Lee \& Pang, 2013). Other research findings also state that students with good abilities and knowledge about job vacancies will find it easier to find work (Baert et al., 2021; Hou et al., 2020). It can be concluded that the implementation of career-related information service programs is essential for students. This research implies that career information service programs should be continued or maintained and developed because they positively influence students, alumni, and community.

\section{SIMPULAN}

The context (context evaluation) of the implementation of career information service activities has been said to be very good, but the drawback is the indicators. Input (input evaluation) has been very good. The process (process evaluation) is good because it is by the benchmark, but for improvements at the stage after carrying out the service, there is an evaluation of service participants. The product (evaluation of results) as a whole is said to be good.

\section{DAFTAR PUSTAKA}

Abulhassn, A., \& Roberts, E. P. L. (2021). Exploring the impact of an NSERC Create program on job readiness among science and engineering graduate students and postdoctoral fellows. Education for Chemical Engineers, 36. https://doi.org/10.1016/j.ece.2021.06.002.

Aggari, M. I., Diño, M. J. S., \& Orte, C. J. S. (2020). Leaders shaping leadership: Knowledge, professional values and competency as prognosticators of career growth and development among nurses. Enfermería Clínica, 30(1). https://doi.org/10.1016/j.enfcli.2019.09.020.

Aghaei, N., Babamohamadi, H., Asgari, M. R., \& Dehghan-Nayeri, N. (2021). Barriers to and facilitators of nursing students' adjustment to internship: A qualitative content analysis. Nurse Education Today, 99. https://doi.org/10.1016/j.nedt.2021.104825.

Alfaiz, A., Hidayat, H., Yandri, H., Tina, A., Sari, L., Sendayu, F. S., Suarja, S., \& Arjoni, A. (2021). Identification of Perceived Self-Efficacy to Predict Student 's Awareness in Career Readiness. Islamic Guidance and Counseling Journal, 4. https://doi.org/0000-0003-1226-0443.

Baert, B. S., Neyt, B., Siedler, T., Tobback, I., \& Verhaest, D. (2021). Student internships and employment opportunities after graduation: A field experiment. Economics of Education Review, 83. https://doi.org/10.1016/j.econedurev.2021.102141.

Baruffaldi, S., Visentin, F., \& Conti, A. (2016). The productivity of science \& engineering PhD students hired from supervisors' networks. Research Policy, 45(5). https://doi.org/10.1016/j.respol.2015.12.006

Briscoe, J. P., Kaše, R., Dries, N., Dysvik, A., \& Unite, J. A. (2021). Here, there, \& everywhere: Development and validation of a cross-culturally representative measure of subjective career success. Journal of Vocational Behavior, 130. https://doi.org/10.1016/j.jvb.2021.103612.

Buenconsejo, J. U., \& Datu, J. A. D. (2020). Growth and fixed mindsets about talent matter for career development self-efficacy in selected Filipino adolescents. Children and Youth Services Review, 118. https://doi.org/10.1016/j.childyouth.2020.105470.

Chan, C. C. (2020). Social support, career beliefs, and career self-efficacy in determination of Taiwanese college athletes' career development. Journal of Hospitality, Leisure, Sport \& Tourism Education, 26. https://doi.org/10.1016/j.jhlste.2019.100232.

Chan, C. S. C. (2021). Helping university students discover their workplace communication needs: An eclectic and interdisciplinary approach to facilitating on-the-job learning of workplace communication. English for Specific Purposes, 64. https://doi.org/10.1016/j.esp.2021.07.002.

Creed, P. A., Conlon, E. G., \& Zimmer-Gembeck, M. J. (2012). Career barriers and reading ability as correlates of career aspirations and expectations of parents and their children. Journal of 
Vocational Behavior, 70(2). https://doi.org/10.1016/j.jvb.2006.11.001.

Crowne, K. A., Brown, M., Durant, D., Baburaj, Y., \& Hornberger, P. (2020). A program for embedding career activities in multiple core business courses. The International Journal of Management Education, 18(3). https://doi.org/10.1016/j.ijme.2020.100421.

Duprez, V., Vermote, B., Hecke, A. Van, Verhaeghe, R., \& Vansteenkiste, M. (2021). Are internship experiences during a pandemic related to students' commitment to nursing education? A crosssectional study. Nurse Education Today, 107. https://doi.org/10.1016/j.nedt.2021.105124.

Emamaullee, J., Ingraham, A., Johnston, F., Fahrenholtz, M., Goldstein, A. M., \& Keswani, S. G. (2021). Mentored career development awards for the development of surgeon-scientists. Surgery, 1. https://doi.org/10.1016/j.surg.2021.04.032.

Harianti, A., Malinda, M., Nur, N., Suwarno, H. L., Margaretha, Y., \& Kambuno, D. (2020). Peran Pendidikan Kewirausahaan Dalam Meningkatkan Motivasi, Kompetensi Dan Menumbuhkan Minat Mahasiswa. Jurnal Bisnis Dan Kewirausahaan, 16(3). https://doi.org/10.31940/jbk.v16i3.2194.

Hirschi, A., Johnston, C. S., Fruyt, F. De, Ghetta, A., \& Orth, U. (2021). Does success change people? Examining objective career success as a precursor for personality development. Journal of Vocational Behavior, 127. https://doi.org/10.1016/j.jvb.2021.103582.

Ho, H. H., Rasdi, R. M., Ibrahim, R., \& Khambari, M. N. M. (2020). Developing and evaluating the effectiveness of mobile phone-based career intervention for career competencies of Malaysian public managers: Protocol for a mixed method study. Internet Interventions, 22. https://doi.org/10.1016/j.invent.2020.100349.

Hou, L., Wang, C., Bai, X., \& Tang, X. (2020). "Life is like this, not as good as poetry": The lived experience of a Chinese rural vocational school student in a mandatory quasi-employment internship. Children and Youth Services Review, 109. https://doi.org/10.1016/j.childyouth.2019.104678.

Indayani, S., \& Hartono, B. (2020). Analisis Pengangguran dan Pertumbuhan Ekonomi sebagai Akibat Pandemi Covid-19. Jurnal Ekonomi Dan Manajemen Universitas Bina Sarana Informatika, 18(2). https://doi.org/10.31294/jp.v18i2.8581.

Ives, R. C., Klein, K. C., \& Mason, N. A. (2020). Career and professional development services for pharmacy students. Currents in Pharmacy Teaching and Learning, 12(9). https://doi.org/10.1016/j.cptl.2020.04.026.

Kautish, P., Hameed, S., Kour, P., \& Walia, S. (2021). Career beliefs, self-efficacy and VUCA skills: A study among generation $\mathrm{Z}$ female students of tourism and hospitality. Journal of Hospitality, Leisure, Sport \& Tourism Education, 1. https://doi.org/10.1016/j.jhlste.2021.100340.

LaForce, M., Noble, E., \& Blackwell, C. (2017). Problem-Based Learning (PBL) and Student Interest in STEM Careers: The Roles of Motivation and Ability Beliefs. Education Sciences, 7(4), 92. https://doi.org/10.3390/educsci7040092.

Lee, Lee, P. C., Dopson, L. R., \& Yoon, S. (2020). What dimensions of career expos have the most impact on student satisfaction? Journal of Hospitality, Leisure, Sport \& Tourism Education, 27. https://doi.org/10.1016/j.jhlste.2020.100263.

Lee, P. L., \& Pang, V. (2013). Motivational factors in continuing education an academic achievement of adult learners. Malaysian Journal of Learning and Instruction.

Loyarte-López, E., García-Olaizola, I., Posada, J., Azúa, I., \& Flórez, J. (2020). Sustainable career development for R\&D professionals: Applying a career development system in Basque country. International Journal of Innovation Studies, 4(2). https://doi.org/10.1016/j.ijis.2020.03.002.

McAleavy, T., Choi, B., \& Arlikatti, S. (2021). Faceless heroes: A content analysis of determinants for the recruitment, career development \& retention of Emergency Medical Dispatchers in the United States of America. International Journal of Disaster Risk Reduction, 61. https://doi.org/10.1016/j.ijdrr.2021.102335.

Rakhab, A., Jackson, C., Nilmanat, K., Butterworth, T., \& Kane, R. (2021). Factors supporting career pathway development amongst advanced practice nurses in Thailand: A cross-sectional survey. International Journal of Nursing Studies, 117. https://doi.org/10.1016/j.ijnurstu.2021.103882.

Shubeck, S. P., Newman, E. A., Vitous, C. A., Antunez, A. G., \& Dossett, L. A. (2020). Hiring Practices of US Academic Surgery Departments-Challenges and Opportunities for More Inclusive Hiring. Journal of Surgical Research, 254. https://doi.org/10.1016/j.jss.2020.03.054.

Smithson, M., McLeod, M. C., Chu, D. I., Kennedy, G., Morris, M., Chen, H., \& Hardiman, K. M. (2021). NIH Funding of Researchers in Surgery: Decreased Career Development Awards Over Time. Journal of Surgical Research, 266. https://doi.org/10.1016/j.jss.2021.02.053.

Steeb, D. R., Zeeman, J. M., Bush, A. A., Dascanio, S. A., \& Persky, A. M. (2021). Exploring career development through a student-directed practicum to provide individualized learning experiences. Currents in Pharmacy Teaching and Learning, 13(5). 
https://doi.org/10.1016/j.cptl.2021.01.020.

Storm, L. K., Henriksen, K., Stambulova, N. B., Cartigny, E., \& Ryba, T. V. (2021). Ten essential features of European dual career development environments: A multiple case study. Psychology of Sport and Exercise, 54. https://doi.org/10.1016/j.psychsport.2021.101918.

Sugianto, S., \& Yul, Y. T. P. (2020). Faktor Penyebab Pengangguran Dan Strategi Penanganan permasalahan Pengangguran Pada Desa Bojongcae, Cibadak Lebak Provinsi Banten. Ikra-Ith Ekonomika, 3(2). https://journals.upi-yai.ac.id/index.php/IKRAITH-EKONOMIKA/article/view/583.

Vasli, P., Shahsavari, A., \& Estebsari, F. (2021). The predictors of nursing students' clinical competency in pre-internship objective structured clinical examination: The roles of exam anxiety and academic success. Nurse Education Today, 1. https://doi.org/10.1016/j.nedt.2021.105148.

Veselova, I., Khimich, G., \& Terentieva, E. (2021). The role of foreign language internships in cultural enrichment and increasing motivation for Russian students to learn Spanish. Heliyon, 7(9). https://doi.org/10.1016/j.heliyon.2021.e08006.

Wilkins, S., Hazzam, J., \& Lean, J. (2021). Doctoral publishing as professional development for an academic career in higher education. The International Journal of Management Education, 19(1). https://doi.org/10.1016/j.ijme.2021.100459.

Yada, A., Björn, P. M., Savolainen, P., Kyttälä, M., \& Aro, M. (2021). Pre-service teachers' self-efficacy in implementing inclusive practices and resilience in Finland. Teaching and Teacher Education, 105. https://doi.org/10.1016/j.tate.2021.103398.

Yamao, S., Yoshikawa, T., Choi, D., \& Toh, S. M. (2020). When do host country nationals help expatriates? The roles of identification with the multinational enterprise and career development support by the subsidiary. Journal of International Management, 26(3). https://doi.org/10.1016/j.intman.2020.100778.

Yano, E. M., Resnick, A., Gluck, M., Kwon, H., \& Mistry, K. B. (2021). Accelerating learning healthcare system development through embedded research: Career trajectories, training needs, and strategies for managing and supporting embedded researchers. Healthcare, 8(1). https://doi.org/10.1016/j.hjdsi.2020.100479. 